\title{
Makna Prinsip Kehati-Hatian dalam Peraturan Daerah Rencana Tata Ruang Wilayah Berbasis Keberlanjutan Lingkungan Hidup di Provinsi Maluku
}

\author{
La 0 deAngga
}

DATA NASKAH

Masuk: 18 Februari 2012

Diterima: 24 Agustus 2017

Terbit: 1 Desember 2017

KORESPONDEN PENULIS:

Fakultas Hukum Universitas Pattimura Ambon,

Jl. Ir. M. Putuhena, Poka, Tlk. Ambon, Kota Ambon, Maluku

laodeangga@yahoo.com

\section{ABSTRACT}

Precautionary Principles in the protection and environmental management in the field of RTRW in M aluku Province on Regional Regulation N 0.16 of 2013 on RTRW is a law regulating the livelihood of M aluku people in the field of spatial plan which aims to create a spatial that can give birth to the welfare of the community in the spatial area. In order to minimize the occurrence of conflicts or disputes that occur in the field of arrangement space in $\mathrm{M}$ aluku Province. Welfare State Theory of the provincial government should take a role in the formation of the RTRW law. Provincial RTRW of M aluku Law does not mention the Precautionary Principles because: a. Philosophical A spects, Perda RTRW N 0. 16 of 2013 does not inspire or reflect A rticle $2 f$ of U U PPL H -2009 and Article 55-59 of U UPR as the higher Law in Spatial Planning in Indonesia; $b$. Juridical A spects The existence of the synchronization of laws and regulations, particularly the Regional Regulation on RTRW of M aluku Province $\mathrm{N} O$. 16 of 2013-2033 with U UPPLH -2009 where in the RTRW regulation there is no Precautionary Principles regulation, whereas in U U PPLH -2009 itself has set clear and precise regulation of prudential principles A rticle $2 f$ and A rticle 44; c. Political A spects The existence of unclear orientation of political vision for the forming of Perda RTRW N 0. 16 of 2013, on the other hand the Provincial RTRW Law of M aluku based on environmental sustainability but there is no Precautionary Principles regulation.

K eywords: M eaning, Precautionary Principles, Bylaws RTRW Sustainable Environment.

ABSTRAK

Makna prinsip kehati-hatian dalam perlindungan dan pengelolaan 
lingkungan hidup di bidang RTRW di Provinsi Maluku terwujud dalam Perda No. 16 Tahun 2013 tentang RTRW yang mengatur hajat hidup orang Maluku di bidang rencana tata ruang wilayah. Perda ini bertujuan untuk menciptakan tata ruang yang mampu melahirkan kesejahteraan masyarakat di bidang tata ruang wilayah, sehingga nantinya akan meminimalisir terjadinya konflik atau sengketa yang terjadi di bidang penataan ruang di Provinsi Maluku. Menurut Teori Negara Kesejahteraan pemerintah daerah Provinsi harus mengambil peran dalam pembentukan Perda RTRW tersebut. Dalam Perda RTRW Provinsi Maluku tidak mencantumkan pengaturan prinsip kehati-hatian karena: a. Aspek Filosofis; Perda RTRW No. 16 Tahun 2013 tidak menjiwai atau mencerminkan Pasal $2 f$ U U PPLH 2009 dan Pasal 55-59 U U PR sebagai U ndang-U ndang yang lebih tinggi dalam Penataan Ruang di Indonesia. b. Aspek Yuridis; Adanya insinkronisasi peraturan perundang-undangan khususnya Perda RTRW Provinsi Maluku No. 16 Tahun 2013-2033 dengan U U PPLH 2009 dimana dalam Perda RTRW tersebut tidak ada pengaturan prinsip kehati-hatian, padahal dalam U U PPLH-2009 itu sendiri telah mengatur secara jelas dan pasti pengaturan prinsip kehati-hatian Pasal $2 f$ dan Pasal 44. c. Aspek Politik; A danya ketidakjelasan orientasi visi politik bagi pembentuk Perda RTRW No. 16 Tahun 2013, disatu sisi Perda RTRW Provinsi Maluku berbasis kebelanjutan lingkungan hidup namun belum ada pengaturan prinsip kehati-hatian.

K eywords: M akna, Prinsip K ehati-H atian, Perda RTRW, K ebelanjutan Lingkungan $\mathrm{H}$ idup

\section{PENDAHULUAN}

M embahas tentang makna pinsip kehati-hatian dalam perlindungan dan pengelolaan lingkungan hidup di bidang RTRW adalah membahas tentang makna prinsip kehati-hatian dalam pengelolaan sumber daya alam dan lingkungan hidup di bidang RTRW di Indonesia. Prinsip kehati-hatian atau pencegahan dini dalam produk hukum nasional Indonesia telah diatur secara tegas di dalam Pasal $2 \mathrm{f}$ dan penjelasannya Undang-Undang No. 32 Tahun 2009 tentang Perlindungan dan Pengelolaan Lingkungan Hidup, Lembaran Negara Republik Indonesia Tahun 2009 No. 140 Tambahan Lembaran Negara Republik Indonesia No. 5059, yang selanjutnya dalam penulisan ini disebut UUPPLH-2009. Pasal $2 f$ UUPPLH2009 menyatakan perlindungan dan pengelolaan lingkungan hidup dilaksanakan berdasarkan asas kehati-hatian. Penjelasan Pasal 2 f UUPPLH-2009 menyatakan yang dimaksud dengan asas kehati-hatian adalah bahwa:

"K etidakpastian mengenai dampak suatu usaha dan/ atau kegiatan karena keterbatasan penguasaan ilmu pengetahuan dan teknologi bukan merupakan alasan untuk menunda langkah-langkah meminimalisasi atau menghindari ancaman tehadap pencemaran dan/atau kerusakan lingkungan hidup".

UUPPLH-2009 merupakan payung bagi setiap peraturan perundang-undangan di bidang pengelolaan sumber daya alam, lingkungan hidup dan penataan ruang. Jadi setiap peraturan perundang-undangan yang mengatur pengelolaan SDA, Lingkungan Hidup dan Penataan Ruang harus berdasarkan UUPPLH-2009 sebagai acuan dasar pembentukan peraturan perundang-undangan tersebut.

Konsep penataan ruang dengan kaidah pembangunan berkelanjutan, dimaksudkan bahwa pola penyediaan ruang harus menjamin pembangunan berkelanjutan, yakni harus menjamin ketersediaan lapangan kerja yang memadai guna dapat menyerap tenaga kerja yang makin lama makin menumpuk di wilayah perkotaan, menjamin kelestarian dan keseimbangan lingkungan, pemerataan akses, harus ada keterlibatan secara aktif dari berbagai pelaku pembangunan, khususnya masyarakat luas, dan hendaknya perencanaan tata ruang dan pembangunan yang hemat energy, tidak memboroskan sumber daya yang dimiliki, baik yang terbarukan maupun tidak terbarukan (Arba, 2013:231). Perda No. 16 Tahun 2013 tentang RTRW Provinsi Maluku maka Perda No. 16 Tahun 2013 tentang RTRW Provinsi Maluku adalah merupakan Perda yang mengatur hajat hidup orang banyak di bidang tata ruang wilayah di Provinsi Maluku yang bertujuan untuk mengatur tata ruang wilayah provinsi Maluku demi terciptanya kesejahteraan dan kehidupan yang layak di bidang penataan ruang, di seluruh pemangku kepetingan di daerah ini.

Di dalam Perda No. 16 Tahun 2013 tentang RTRW Provinsi Maluku belum adanya pengaturan mengenai prinsip kehati-hatian pencegahan dini, dan/atau pencegahan antisipatif (Precautionary principle) khususnya pada Pasal 4 
yang mengatur tentang Azas, Tujuan. Tidak adanya pengaturan prinsipkehati-hatian pencegahan dini, dan/atau pencegahan antisipatif (Precautionary principle), dalam pengaturan Perda No. 16 Tahun 2013 maka Perda No. 16 Tahun 2013 tidak sinkron (insinkronisasi) dengan Pasal $2 f$ dan penjelasannya dan Pasal 44 UUPPLH-2009 yang telah menganut secara tegas prinsip kehati-hatian dalam perlindungan dan pengelolaan lingkungan hidup di Indonesia.

Tidak adanya pengaturan prinsip kehati-hatian pencegahan dini, dan/atau pencegahan antisipatif (Precautionary principle) dalam Perda No. 16 Tahun 2013 tentang RTRW Provinsi Maluku maka Perda No. 16 Tahun 2013 tentang RTRW Provinsi Maluku tidak sinkron (insinkronisasi) dengan Pasal $2 \mathrm{f}$ dan penjelasannya serta Pasal 44 UUPPLH-2009. Bertolak dari uraian di atas, maka isu hukum (legal issue) dalam penelitian ini adalah "belum adanya prinsip kehatihatian, dan pencegahan antisipatif (Precautionary principle) yang telah diatur lebih dahulu dalam UUPPLH-2009. Adanya peraturan perundang-undangan yang lebih rendah yang tidak sinkron dengan peraturan yang lebih tinggi. Dalam hal ini Perda No. 16 Tahun 2013 tentang RTRW Provinsi Maluku tidak sinkron (insinkronisasi) dengan Pasal $2 f$ dan penjelasannya dan Pasal 44UUPPLH-2009.

\section{RUMUSAN MASALAH}

Selanjutnya, isu hukum (legal issue) tersebut dirinci dalam dua (2) sub masalah yaitu:

1. Apa makna prinsip kehati-hatian dalam perlindungan dan pengelolaan lingkungan hidup di bidang RTRW di Provinsi Maluku?

2. M engapa dalam Perda No. 16 Tahun 2013 tentang RTRW Provinsi Maluku tidak mencantumkan pengaturan prinsip kehati-hatian?

\section{METODE PENELITIAN}

\section{A. Jenis Penelitian}

Penelitian ini adalah jenis penelitian hukum normatif yaitu penelitian hukum yang obyek kajiannya meliputi ketentuanketentuan perundang-undangan dan bahan-bahan hukum yang bersifat dokumenter, dengan pokok kajian masalah makna prinsip kehati-hatian dalam Perda Rencana Tata Ruang
Wilayah yang berkelanjutan Provinsi Maluku. Dalam penelitian ini juga akan menggali, mengumpulkan, memaparkan dan menganalisis fakta hukum yang terdapat dalam pasal-pasal UUPPLH-2009 dan Undang-Undang No. 26 Tahun 2007 tentang Penataan Ruang, Lembaran Negara Republik Indonesia Tahun 2007 No. 68, Tambahan Lembaran Negara Republik Indonesia No. 4725, selanjutnya disebut UUPR-2007 peraturan perundangan yang ada di bawahnya dengan Prinsip Kehati-hatian Dalam Perda RTRW berbasis keberlanjutan lingkungan hidup di Provinsi M aluku.

\section{B. Pendekatan Penelitian}

Di dalam penelitian ini menggunakan beberapa pendekatan. Dengan pendekatan yang dimaksud, peneliti dapat memperoleh informasi berbagai aspek mengenai issue yang diteliti untuk mendapat jawabanya. Pendekatanpendekatan yang digunakan dalam penelitian adalah pendekaan filosofis (philosophical approach), pendekatan perundang-undangan (statute approach), dan pendekatan konseptual (conseptual approach), (Peter M ahmud Marzuki, 2008: 5).

Pendekatan filosofis, pendekatan perundang-undangan, dan Pendekatan konseptual mengkaji semua aturan hukum, konsep atau doktrin hukum, dan asas hukum yang terkait dengan makna prinsip kahati-hatian dalam Perda RTRW berbasis keberlanjutan lingkungan hidup di Provinsi Maluku untuk kemudian direfleksi dan diberi argumentasi teoritik guna menjawab pertanyaan penelitian.

\section{Bahan Hukum}

Penelitian ini menggunakan bahan hukum primer dan sekunder. Bahan hukum primer penelitian ini adalah perundang-undangan yang terkait dengan perlindungan dan pengelolaan lingkungan hidup serta penataan ruang yang berlaku di Indonesia, dan peraturan kebijakan yang terkait dengan masalah penelitian ini. Adapun bahan hukum primer dalam penelitian ini yaitu:

1. Undang-Undang No. 32 Tahun 2009 tentang Perlindungan dan Pengelolaan Lingkungan Hidup, (Lembaran Negara Republik Indonesia Tahun 2009 No. 140 Tambahan Lembaran Negara Republik Indonesia No. 5059); 
2. Undang-Undang No. 26 Tahun 2007 tentang Tata Ruang (Lembaran Negara Republik Indonesia Tahun 2007 No. 68 Tambahan Lembaran Negara Republik Indonesia No. 4725);

3. Peraturan Daerah Provinsi M aluku No. 16 Tahun 2013 tentang Rencana Tata Ruang Wilayah Provinsi M aluku Tahun 2013-2033, (Lembaran Daerah Provinsi M aluku No. 16 tahun 2013);

4. Risalah Rapat kerja Badan Legislasi DRPD Provinsi M aluku Bersama Eksekutif Dalam Rangka Pembahasan Ranperda Usulan Pemerintah Daerah tentang RTRW Provinsi Maluku.

Bahan hukum sekunder yaitu; buku, dokumen resmi, hasil-hasil penelitian, jurnal ilmiah yang memiliki keterkaitan terhadap permasalahan ini, seperti:

1. Berbagai data kepustakaan, yang berkaitan dengan prinsip kehati-hatian dalam Perda RTRW berbasis keberlanjutan lingkungan hidup di Provinsi Maluku;

2. Berbagai tesis, disertasi, hasil penelitian, karya ilmiah, jurnal, makalah dan artikel mengenai perlindungan dan pengelolaan lingkungan hidup;

3. Berbagai hasil seminar.

\section{Teknik Pengumpulan Bahan H ukum}

Prosedur penelusuran bahan hukum dilakukan melalui tahapan: pertama, melakukan penelusuran bahan hukum primer yang berupa produk hukum peraturan perundangundangan di bidang Rencana Tata Ruang Wilayah dan perlindungan dan pengelolaan lingkungan hidup termaksud sumber daya alam, yang terkait dengan isu hukum yang diteliti, bahan hukum sekunder; kedua, sistematisasi peraturan perundang-undangan. Sistematisasi peraturan perundang-undangan ini dilakukan untuk menggali sekaligus melakukan inventarisasi peraturan terkait dengan Prinsip kehati-hatian dalam Peraturan daerah Rencana Tata Ruang Wilayah Berbasis Keberlanjutan Lingkungan di Provinsi Maluku; ketiga, melakukan klasifikasi peraturan perundangundangan terkait dengan Prinsip kehati-hatian dalam Perda RTRW Provinsi Maluku. Klasifikasi ini dilakukan atas dasar pendekatan hirarkhis yang bertujuan untuk memudahkan proses menganalisis. Bahan hukum yang sudah diperoleh kemudian dicatat, diedit, dipelajari dan diambil intisarinya dalam bentuk teori, ide, konsep, argumentasi maupun ketentuan-ketentuan hukum terkait; keempat, menganalisis yaitu menganalisis bahan hukum yang telah diklasifikasi, yaitu peraturan perundang-undangan terkait dengan Makana prinsip kehati-hatian dalam Perda RTRW Berbasis Keberlanjutan Lingkungan Hidup di Provinsi Maluku.

\section{E. Analisis Bahan H ukum}

Seluruh bahan hukum yang diperoleh melalui dokumentasi, dipelajari dan dianalisis secara mendalam sehingga diperoleh suatu kesimpulan yang utuh dan mendalam. Teknik yang digunakan untuk menganalisis bahan hukum, baik bahan hukum primer maupun bahan hukum sekunder yang telah terkumpul dari studi dokumen serta bahan pustaka diidentifikasi lalu dikelompokkan, ditelaah serta diuraikan menurut hirarkhirnya.

\section{HASIL PENELITIAN DAN ANALISIS}

Dalam penulisan ini, penulis menggunakan dua Teori sebagai pisau analisis untuk menjawab permasalahan yang ada, yaitu: Teori Negara Kesejahteraan sabagai Grand Theory, dan Teori Kostitusi Hijau (The Green Contitution) Applied Theory. Teori Negara Kesejahteraan digunakan untuk menganalisis rumusan masalah pertama, sedangkan Teori Kostitusi Hijau digunakan untuk menganalisis rumusan masalah yang kedua.

A. Analisis Makna prinsip kehati-hatian dalam perlindungan dan pengelolaan lingkungan hidup di bidang RTRW di Provinsi Maluku

Dalam pandangan Teori Negara Kesejahteraan bahwa Negara atau Pemerintah, pemerintah Provinsi Kabupaten/ Kota, dianggap tidak dapat melepaskan tanggungjawabnya dalam meningkatkan kesejahteraan masyarakat. Bahwa negara atau pemerintah pada level apapun perlu turut campur dalam pengaturan pengelolaan sumberdaya alam dan lingkungan hidup termasuk penataan ruang (rencana tata ruang wilayah) dengan tujuan agar sumber-sumber kemakmuran rakyat tidak dikuasai oleh segelintir orang saja. Dalam teori negara kesejahteraan, bahwa tugas negara atau pemerintah atau pemerintah Provinsi Kabupaten/Kota, dalam penyelenggaraan kepentingan umum menjadi sangat luas, kemungkinan melanggar kepentingan rakyat oleh perangkat 
negara atau Pemerintah, pemerintah Provinsi Kabupaten/Kota, juga menjadi sangat luas. Dalam melaksanakan tugas tersebut, maka administrasi negara memerlukan kemerd ekaan, yaitu kemerdekaan untuk dapat bertindak atas inisiatif sendiri terutama dalam menyelesaikan soal-soal genting yang timbul dimana regulasi belum ada. Karena demikian luasnya fungsi pemerintah dalam konteksnegara hukum modern atau negara kesejahteraan ini, maka tentu saja semakin luas peran hukum administrasi di dalamnya.

Hubunganya dengan Makna prinsip kehati-hatian dalam perlindungan dan pengelolaan lingkungan hidup di bidang RTRW di Provinsi Maluku, menurut Teori Negara Kesejahteraan yaitu; bahwa Perda No. 16 Tahun 2013 tentang RTRW adalah merupakan Perda yang mengatur hajat hidup orang Maluku di bidang rencana tata ruang wilayah yang bertujuan untuk menciptakan tata ruang yang mampu melahirkan kesejahteraan masyarakat di bidang tata ruang wilayah, sehingga nantinya akan meminimalisir (mengurangi) konflik atau sengketa yang terjadi di bidang penataan ruang di Provinsi Maluku. Dalam mewujudkan hal tersebut menurut Teori Negara Kesejahteraan pemerintah daerah Provinsi harusmengambil peran dalam pembentukan Perda RTRW tersebut.

M enurut teori negara hukum kesejahteraan, salah satu tugas negara atau pemerintah dan pemerintah daerah adalah sebagai penyelenggara kepentingan umum. Kepentingan umum ini menjadi sangat luas, kemungkinan melanggar kepentingan rakyat oleh perangkat negara atau daerah juga menjadi sangat luas. Dalam melaksanakan tugas tersebut, maka administrasi negara memerlukan kemerdekaan, yaitu kemerdekaan untuk dapat bertindak atas inisiatif sendiri terutama dalam menyelesaikan soal-soal genting yang timbul dimana regulasi belum ada. Karena demikian luasnya fungsi pemerintah dan pemerintah daerah dalam konteks negara hukum modern atau negara hukum kesejahteraan ini, maka tentu saja semakin luas peran hukum administrasi di dalamnya, masuk juga di dalamnya urusan pembentukan Perda RTRW Provinsi Maluku yang bertujuan untuk mesenjahterakan masyarakat Maluku di bidang penataan wilayah khususnya pesisir dan pulau-pulau kecil.

B. Analisis Perda No. 16 Tahun 2013 tentang RTRW Provinsi
M aluku Tidak mencantumkan pengaturan prinsip kehatihatian

Untuk menganalisispermasalahan kedua dalam penulisan ini, penulis menggunakan teori konstitusi hijau sebagai pisau analisis. Konstitusi hijau atau (green constitution) dalam dinamika ketatanegaraan Indonesia baik dalam tataran praktis maupun akademis, tidak dapat dibantah merupakan suatu fenomena baru bagi yang belum mengetahuinya. Gagasan yang secara substansial mengarah pada muatan konstitusi hijau antara lain yang dikemukakan oleh Heinlard Stieger (1980;4). Dalam tulisannya, dikemukakan gagasan perlunya jaminan perlindungan hak-hak lingkungan hidup kedalam konstitusi, khususnya hak-hak lingkungan individual (individual's environment). Stieger menyatakan:

"The subjective rights are devided in two groups according to their their legal guarantee: the fundamental rights at the constitutional level and the ordinary legislation. Fundamental rights are of essential importance for the constitutional and legal order. 0 rdinary subjective rights below the constitutional level enjoy less legal proktection than constitutional subjeltive rights" (H einhard Steiger, 1980: 3).

Sebenarnya hak-hak lingkungan yang dapat menjadi muatan konstitusi tidak hanya terbatas pada hak-hak subyektif, tetapi juga hak-hak lain seperti hak-hak prosedural dan hak-hak lingkungan yang didasarkan pada nilai intriksik alam itu sendiri. Dengan jaminan konstitusional hususnya Pasal 28H ayat (1) dan Pasal 33 ayat (4) dan pada tataran operasional sebagai peraturan pelaksanaan Pemerintah bersama DPRI telah membentuk UUPPLH-2009 yang di dalamnya mengatur mengenai asas kehati-hatian atau prinsip kehati-hatian. Yang menjadi persoalan mengapa dalam pembetukan Perda No. 16 Tahun 2013 tentang RTRW Provinsi Maluku belum mengatur asas/prinsip kehati-hatian tersebut. Dalam pembentukan Peratran perundangundangan tentu saja ada beberapa aspek yang muncul di dalam diantara;

\section{Aspek Filosofis}

M enurut Bagirmanan, setiap peraturan perundangan baik dalam proses pembentukannya materi muatan maupun dalam pelaksanaannya, harus mencerminkan nilai cita hukum bersama. Cita hukum ini tumbuh dari sistem nilai masyarakat mengenai baik atau buruk dan pandangan hidup 
masyarakat yang semuanya menyangkut pandangan mengenai hakekat sesuatu. Hukum dalam hal ini peraturan perundang-undangan harus mencermingkan adanya sistem nilai tersebut. Nilai-nilai ini ada yang dibiarkan dalam masyarakat, sehingga para pembentukundang-undang harus mampu menangkapnya namun ada juga yang terangkum dengan baik berupa teori filsafat dan doktrin resmi seperti Pancasila, (Bagir manan, dalam Yuliandri; 1999). Pernyataan Bagir Manan tersebut dimaksudkan bahwa, cita hukum sebagai landasan filosofis bangsa harus dijadikan pedoman oleh para pembentuk undang-undang dalam proses pembentukan (aspek formil) maupun ketika menyusun materi muatan sebuah peraturan perundangan (aspek materiil).

Pembentukan peraturan perundang-undangan merupakan proses perwujudan nilai yang terkandung dalam cita hukum kedalam norma hukum, sehingga sangat tergantung pada tingkat kesadaran dan penghayatan pembentuk undang-undang. Kurangnya kesadaran dan penghayatan akan nilai tersebut, menimbulkan kesenjangan antara cita hukum dan norma hukum yang dibuat. Negara Republik Indonesia yang memiliki cita hukum Pancasila, sekaligus sebagai norma fundamental negara, maka setiap peraturan harus diwarnai oleh nilai-nilai yang terkandung dalam cita hukum tersebut, yaitu Pancasila. Hal tersebut senada dengan pemikiran A. Hamid Attamimi, bahwa Pancasila sebagai cita hukum bagi bangsa Indonesia harus dijadikan sebagai bintang pemandu.

Pendapat di atas baik Bagir Manan maupun A. Hamid Attamimi sejalan dengan konsep konstitusi hijau dalam UUD 1945. Konstitusionalisasi lingkungan hidup dalam konstitusi Indonesia sendiri sudah dilakukan dalam amandemen kedua UUD 1945, namun tidak banyak pihak yang memperhatikan hal ini secara serius. Pasal 28H ayat (1) dan Pasal 33 ayat (4) UUD 1945 merupakan bukti bahwa konstitusi Indonesia adalah Konstitusi Hijau (Green Constitution).

Kaitanya dengan Perda No. 16 Tahun 2013 tentang RTRW Provinsi Maluku selain dilihat dari cita hukum Indonesia yaitu Pancasila juga lebih lanjut harus memuat prinsip-prinsip/ asas-asas yang dianut baik dalam UUD 1945, UUPA, UUPPLH maupun UUPR, ketika menyusun Perda No. 16 Tahun 2013 tentang RTRW Provinsi Maluku materi muatan (aspek materiil), tujuan utamanya adalah pada konstitusional lingkungan.

\section{Aspek Yuridis}

Merujuk pada ilmu perundang-undangan bahwa Peraturan Perundang-undangan yang baik harus memperhatikan salah satunya adalah landasan yuridis dari penyusunannya. Artinya harus mempunyai dasar hukum, legalitas atau landasan yang terdapat dalam ketentuan hukum yang lebih tinggi derajatnya. Landasan yurid is dari suatu peraturan Perundang-undangan, ditempatkan dalam bagian "M engingat", (Yuliandri; 1999).

Para pembentuk Perda No. 16 Tahun 2013-2033 tentang RTRW Provinsi Maluku seharusnya konsisten dengan landasan yuridis konstitusional yang dituangkan dalam konsiderans "mengingat" termasut dalam Perda No. 16 Tahun 20132033 tentang RTRW Provinsi M aluku tersebut. Tujuan adanya landasan yuridis konstitusional yang tertuang dalam bagian "mengingat" tentunya tidak hanya sekedar sebagai legalitas formal, namun lebih dari itu dimaksudkan juga sebagai legalitas dalam arti material. Artinya pencantuman landasan konstitusional dalam bagian mengingat tidak hanya sekedar memenuhi formalitas dalam sistematika teknik penyusunan perundang-undangan, namun lebih dari itu juga harus dijadikan "jiwa atau ruh" dalam batang tubuh suatu peraturan perundang-undangan, yang dalam hal ini adalah Perda No. 16 Tahun 2013-2033 tentang RTRW Provinsi Maluku yang belum mengatur prinsip kehati-hatian, pencegahan dini, dan/atau tindakan antisipatif (precautionary principle) baik dalam asas maupun dalam norma hukumnya, yang sudah diatur dalam UUPPLH yang merupakan UU terbaru dalam perlindungan dan pengelolaan sumber daya alam dan lingkungan hidup di Indonesia saat ini.

Secara yuridis, yang menyebabkan Perda No. 16 Tahun 2013-2033 tentang RTRW Provinsi M aluku belum mengatur pengawasan dan evaluasi sebagai bagian dari instrumen prinsip kehati-hatian yang sebelumnya sudah diatur dalam Pasal 55-59 UUPR dan UUPPLH yaitu dalam Pasal $2 f$ dan penjelasannya karena pembentuk Perda No. 16 Tahun 20132033 tentang RTRW Provinsi Maluku dalam hal ini DPRD Provinsi Maluku dan Pemerintah Provinsi Maluku belum mengakomodir Pasal 55-59 UUPR dan Pasal 2f UUPPLH dan 
penjelasannya.

Formulasi pengaturan merupakan suatu perencanaan atau program dari pembentuk undang-undang, mengenai apa yang akan dilakukan untukmengatasi permasalahan tertentu tersebut sesuai dengan yang telah direncanakan. Dalam konteks negara kesejahteraan, formulasi pengaturan pengawasan dan evaluasi sebagai bagian dari instrument prinsip kehati-hatian, pencegahan dini, dan/atau tindakan antisipatif (precautionary principle) dalam Perda No. 16 Tahun 2013 tentang RTRW Provinsi Maluku, dimaksudkan sebagai bentuk pertanggungjawaban dalam upaya menjamin keberlansungan lingkungan hidup termasuk penataan ruang yang berkelanjutan di Provinsi Maluku, agar lingkungan hidup tetap terjaga dan bisa dinikmati dari generasi masa kini kepada generasi masa depan. M enurut Jimly Asshiddiqie, negara kesejahteraan menuntut peran negara (pemerintah dan pemerintah daerah) untuk memperluas tanggungjawabnya kepada masalah sosial dan ekonomi yang dihadapi oleh masyatakat, (Jimly Asshiddiqie, 1994; 223). termaksud bagaimana pemerintah daerah Provinsi M aluku bersama DPRD Provinsi Maluku bisa membentuk Perda yang dengan Perda tersebut bisa melahirkan kesejahteraan rakayat.

\section{Aspek Politis}

Setiap pembentukan Perundang-Undangan diikuti dengan berbagai kepentingan. Demikian juga dengan pembentukan Perda No. 16 Tahun 2013 tentang RTRW Provinsi Maluku. Dominasi pemerintah dalam proses pembentukan Perda No. 16 Tahun 2013 tentang RTRW Provinsi Maluku dengan kerangka berpikir berbasis mitigasi bencana mestinya harus lebih banyak mengatur mengenai prinsip kehati-hatian, pencegahan dini, dan/atau tindakan antisipatif (precautionary principle). Pengaturan "berbasis mitigasi bencana" tentu saja menunjukkan ada keinginan dan kemauan politik Pemerintah Provinsi Maluku bersama DRPD Provinsi M aluku untuk melakukan pengawasan dan evaluasi sebagai bagian dari instrumen prinsip kehati-hatian, pencegahan dini, dan/atau tindakan antisipatif (precautionary principle) terhadap perusakan dan pencemaran lingkungan hidup dan di bidang tata ruang wilayah Provinsi M aluku, namun dalam Perda No. 16 Tahun 2013 tentang RTRW Provinsi Maluku belum mengatur mengenai prinsip kehati-hatian atau pencegahan dini yang sebelumnya sudah diatur dalam UUPPLH.

Untuk menemukan jawaban mengapa dalam Perda No. 16 Tahun 2013 tentang RTRW Provinsi Maluku tidak prinsip kehati-hatian atau pencegahan dini maka penulis melakukan penelusuran Risalah Rapat Kerja Badan Legislasi DRPD Provinsi Maluku bersama Eksekutif terkait/mitra dalam pembentukan Perda No. 16 Tahun 2013 tentang RTRW Provinsi Maluku. Di dalam Risalah Rapat Kerja Badan Legislasi DPRD Provinsi Maluku bersama Eksekutif terkait/mitra pembentukan Perda No. 16 Tahun 2013 tentang RTRW Provinsi Maluku pada sidang hari pertama Selasa tanggal 8 Januari 2013 Jam 10.00 WIT yang dihadiri oleh 9 orang Badan Legislasi yang terdiri dari 1 orang ketua dan 8 orang anggota bersama dengan Eksekutif terkait/mitra. Selanjutnya di dalam Risalah Rapat internal Badan Legislasi DPRD Provinsi Maluku mengenai pendapat mini Fraksi-Fraksi terhadap pembentukan Perda RTRW Provinsi Maluku pada hari ketiga yaitu hari Jumat tanggal 11 Januari 2013 dari 15 anggota Badan Legislasi hanya dihadiri oleh 11 orang Badan Legislasi yang terdiri dari 1 orang ketua dan 10 orang anggota. Bila dicermati dari Risalah Rapat pembentukan Perda RTRW Provinsi Maluku dari hari pertama sidang, kedua dan ketiga sidang internal pengambilan kesimpulan, maka tidak ada agenda Risalah Rapat yang pembahasannya mengenai: prinsip kehati-hatian, pencegahan dini, dan/atau (precautionary principle)

\section{KESIMPULAN DAN SARAN}

\section{A. Kesimpulan}

Berdasarkan analisis sebelumnya dapat diperoleh kesimpulan sebagai berikut:

1. Makna prinsip kehati-hatian dalam perlindungan dan pengelolaan lingkungan hidup di bidang RTRW di Provinsi Maluku, menurut Teori Negara Kesejahteraan yaitu; bahwa Perda No. 16 Tahun 2013 tentang RTRW adalah merupakan Perda yang mengatur hajat hidup orang Maluku di bidang rencana tata ruang wilayah yang bertujuan untuk menciptakan tata ruang yang mampu melahirkan kesejahteraan masyarakat di bidang tata ruang wilayah, sehingga nantinya akan meminimalisir (mengurangi) konflik atau sengketa yang terjadi di 
bidang penataan ruang di Provinsi Maluku. Dalam mewujudkan hal tersebut menurut Teori Negara Kesejahteraan pemerintah daerah Provinsi harus mengambil peran dalam pembentukan Perda RTRW tersebut.

2. Dalam Perda RTRW Provinsi Maluku tidakmencantumkan pengaturan prinsip kehati-hatian karena ada beberapa aspek terbentuknya Perda RTRW tersebut;

a. Aspek Filosofis, Perda RTRW No. 16 Tahun 2013 tidak menjiwai atau mencerminkan Pasal $2 \mathrm{f}$ UUPPLH2009 dan Pasal 55-59 UUPR sebagai Undang-undang yang lebih tinggi dalam Penataan Ruang di Indonesia.

b. Aspek Yuridis Adanya insinkronisasi peraturan perundang-undangan khususnya Perda RTRW Provinsi Maluku No. 16 Tahun 2013-2033 dengan UUPPLH2009 dimana dalam Perda RTRW tersebut tidak ada pengaturan pengaturan prinsip kehati-hatian padahal dalam UUPPLH-2009 itu sendiri telah mengatur secara jelas dan pasti pengaturan prinsip kehati-hatian Pasal $2 \mathrm{f}$ dan Pasal 44.

c. Aspek Politik Adanya ketidak jelasan orientasi visi politik bagi pembentuk Perda RTRW No. 16 Tahun 2013, disatu sisi Perda RTRW Provinsi Maluku berbasis kebelanjutan lingkungan hidup namun dalam pengaturan norma belum ada pengaturan prinsip kehati-hatian.

\section{B. Saran}

Berdasarkan analisis dan kesimpulan di atas, maka saran dalam penulisan ini sebagai berikut:

1. Institusi terkait perlu melakukan revisi terhadap pengaturan Perda RTRW No. 16 Tahun 2013-2033 Provinsi Maluku dengan mencantumkan prinsip kehatihatian, yang sudah diatur dalam Pasal $2 f$ dan Pasal 44 UUPPLH-2009.

2. Untuk menciptakan Kepastian Hukum dalam Perda No. 16 Tahun 2013-2033 tentang RTRW maka pengaturan kebijakan yang dikeluarkan oleh Pemerintah Daerah Provinsi Maluku tidak boleh bertentangan baik dengan pengaturan UUD NRI 1945, UUPPLH maupun UUPR.

\section{DAFTAR PUSTAKA}

\section{BUKU}

A sshiddiqie, Jimly, G reen Constitution: $\mathrm{N}$ uansa $\mathrm{H}$ ijau U ndang-U ndang D asar N egara Republik Indonesia Tahun 1945, Jakarta: Rajawali Press, 2009.

G agasan K edaulatan Rakyat dalam $\mathrm{K}$ onsitusi dan Pelaksanaannya di I ndonesia Jakarta I chtisar Van H ove, 1994.

M anan, Bagir, dalam Yuliandri, A sas-asas Pembentukan Peraturan perundangan Yang Baik: Gagasan Pembentukan Undang-U ndang Berkelanjutan, Jakarta: Yayasan Tjoet N yak Dien \& IN PI- Pact, 1999.

Marzuki, Peter Mahmud, Penelitian H ukum, Jakarta: Kencana Prenada Media Group, 2008.

Steiger, H einhard (et. Al), The Fundamental Riight to De cent E nviroment, dalam M ichael Bothe (project coordinator) Trend in E nviromental Policy and Law, Berlin: Erich Schmidt Verlag, 1980.

Yuliandri, A sas-asas Pembentukan Peraturan Perundangan Yang Baik: G agasan Pembentukan U ndang-U ndang B erkelanjutan, Jakarta: Yayasan Tjoet N yak Dien \& IN PI- Pact, 1999.

\section{JURNAL}

Arba, M., 2013, K onsepsi Perlindungan dan Pengelolaan Lingkungan $\mathrm{H}$ idup dalam U U PR dan RTRW Se-Provinsi N usa Tenggara Barat, Jurnal M edia Hukum, Vol. 20 No. 2.

\section{PERATURAN PERUNDANG U NDANGAN}

Undang-U ndang No. 32 Tahun 2009 tentang Perlindungan dan Pengelolaan Lingkungan Hidup, Lembaran N egara Republik Indonesia Tahun 2009 N o. 140 Tambahan Lembaran Negara Republik Indonesia N 0. 5059.

U ndang-U ndang N o. 26 Tahun 2007 tentang Penataan Ruang, Lembaran N egara Republik Indonesia Tahun 2007 No. 68, Tambahan Lembaran N egra Republik Indonesia No. 4725.

Peraturan Daerah Provinsi Maluku No. 16 Tahun 2013 tentang RTRW Provinsi Maluku Tahun 1013-2033, Lembaran Daerah Provinsi Maluku No. 16 Tahun 2013.

Risalah Rapat kerja Badan Legislasi DRPD Provinsi Maluku Bersama Eksekutif Dalam Rangka Pembahasan Ranperda U sulan Pemerintah Daerah tentang RTRW Provinsi Maluku. 